\title{
メニエール病のケース・コントロール研究
}

中江 公裕* 一小松崎 篤**

\section{A Case Control Study on Meniere's Disease}

\author{
Kimihiro Nakae \\ (Dokkyo Univ.)
}

\section{Atsushi Komatsuzaki}

(Tokyo Univ.)

A case-control study of Meniere's disease was made on the pationts with otolaryngological disturbances in Tokyo University Hospital. 14.6 percent of Meniere's disease patients had hypotonia at the time of attack and the percent was significantly higher than 6-8 percent of the control patients.

Mental and/or physical strain, irritation, trouble, lack of sleep and some foods strongy contributed to occurrence of Meniere's disease, although ear-splitting noise, smoking and menstruation had mild effects. As for a sense of tasts, Meniere's disease patients were a little more fond of a sour taste than the control patients.

Meniere's disease patients more rajsed cats than the control patients. There was no difference between both groups regarding history of occupation, medical history, urban and rural factors and complications, except for hypotonia.

Those with long period of attack suspension (long period group) had a higher sex ratio than those with a short period of attack suspension (short period group). In the short period group there was a higher frequency of disturbance of the circulatory system (i.e. arteriosclerosis, hypertension, hypotonia, cerebrovascular disease, heart and/or vascular disease).

The short period group had more raised small birds as pets than the long period group

Monthly occurrence of Meniere's disease showed an increase in spring (MarchMay) and in autumn (August-October).

Average age of onset of Meniere's disease had annually increased.

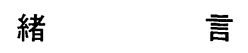

原因不明疾患の病因を明らかにするととを目的として行われる疫学調査の 1 つに, ケース・コン トロール調査がある。乙の方法は, 病因への曝露群一非曝露群の比較調査と異って病因を仮定しな い調查方法であり, 未だ当該疾患の病因叒は遷延因子が明らかでない段階に, 病因の仮説を得るた めの方法として有効であるとされる.

メニェール病の病因又は本態については, 様々の説（内リンパ水腫, アレルギー, 迷路血管神経 症, 頸椎異常, 頭部・音響外傷, 循環障害, ストレス, 水分・塩分代謝異常など）があるが主定説 化されたものはない. 現在, 本症に対するケース・コントロール研究の例が極めて少ないととを以

*独協医科大学公衆衛生学教室

**東京大学医学部耳鼻咽喉科学教室 
上のような学問的背景と併せ考える時, この時点で本症に対しケース・コントロール研究を行うこ とは適切であると考えられる，以下これによって得た若干の知見を報告する。

\section{対象並びに方法}

本症患者の診断は, 反復性の耳鳴・難聴又は 反復性回転性めまい発作を有するもので，それ らの症状が中枢神経疾患又は原因既知の疾患に 由来することが明瞭であるものを除外したもの に対してつけられる ${ }^{2)}$. 従って，本症に特異的 な判断の基準はないので, 類縁疾患又は entity を異にする 2 つ以上の疾患群が調査対象群のな かに混在している可能性が存在する。このよう な疾患の疫学調査では，診断の正確さだけでは なく，診断の均一性を得るととがより重要であ る. 従って，本調查では，診断基準が一定でか つ高い精度で本症からの除外疾患を鑑別した東 大病院耳鼻咽喉科の初診患者 671 名（昭和35～ 50年）を対象とした．対照群としては，受診患 者の社会階層，地域性を考慮して，同上耳鼻咽

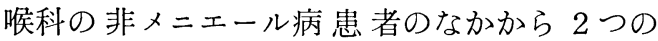
群，すなわち，(1)同上前庭専門外来を昭和 48 年 ～50年 ( 3 年間) 亿初診しためまい患者群1153名 （以下，前庭外来群と略）(2) 同上一般外来を昭 和53年 1 月 1 日〜 10月 31 日に初診した耳鼻咽喉 一般外来患者群（めまい症状を有するものを除 く）（以下，一般外来群と略）を対照群とした. 調査は経費と無駄を少なくするため，まずメ ニエール病患者群 671 名及び前庭外来群1153名 に対し調査票を郵送し，患者本人が回答するよ う指示した結果，メニエール病患者群からは 212名, 前庭外来群からは321名の回答を得た。 次にてれら回答を得たメニエール病群 212 名に 対し，性・年令（現在年令・ 5 才間隔）でマッ チングした 5 倍の一般外来患者群を抽出し, 同 一内容の調査票を郵送して患者本人が回答する よう指示した結果，512 名から回答を得た。

結

表 2 に 3 群の地域分布を示す．埼玉及び神奈 川以西では 3 群はよく一致しているが，北関東
集計にあたっては，個々の調査票をチェック した上で，死亡者からの回答，15才以下の回 答，不明・無記入の多い回答，その他信頼性が 低いと判断される回答を除外し，再び性・年令 (5才間隔) でマッチング比率が $1: 1: 2$ (メ 二エール病群・前庭外来群：一般外来群）とな るようにマッチングした結果（表 1 )，メニエ 一ル病群178名, 前庭外来群178名, 一般外来群 356 名（以下，3 群と略）が解析の対象となっ た。

表 1 性年令分布（メニエール病患者, 前庭外来患者）

\begin{tabular}{|c|c|c|}
\hline \multirow{2}{*}{ 年 } & \multicolumn{2}{|c|}{ 性 } \\
\hline & 男 & 女 \\
\hline $20-24$ & $1(1.1)$ & $0(0.0)$ \\
\hline $25-29$ & $3(3.2)$ & $0(0.0)$ \\
\hline $30-34$ & $6(6.3)$ & $0(0.0)$ \\
\hline $35-39$ & $4(4.2)$ & $9(10.8)$ \\
\hline $40-44$ & $6(6.3)$ & $13(15.7)$ \\
\hline $45-49$ & $18(18.9)$ & $12(14.5)$ \\
\hline $50-54$ & $15(15.8)$ & $12(14.5)$ \\
\hline $55-59$ & $14(14.7)$ & $9(10.8)$ \\
\hline $60-64$ & $10(10.5)$ & $10(12.0)$ \\
\hline $65-69$ & $11(11.6)$ & $5(6.0)$ \\
\hline $70-74$ & $4(4.2)$ & $7(8.4)$ \\
\hline $75-79$ & $2(2.1)$ & $5(6.0)$ \\
\hline $80-84$ & $1(1.1)$ & $1(1.2)$ \\
\hline 計 & $95100 \%$ & $83 \quad 100 \%$ \\
\hline 平均年令 & 53.1才 & $54.8 才$ \\
\hline 標準偏差 & 12.5 & 12.3 \\
\hline 発病年令平均 & $37.4 才$ & $38.7 才$ \\
\hline 標準偏差 & 13.3 & 12.6 \\
\hline
\end{tabular}

注: 年令は昭和 53 年 12 月 31 日現在年令, 耳鼻科一 般患者はこの 2 倍数

果

以北及び千葉県ではメニエール病群が若干多 く，その分だけ東京で少なくなっている，本症 
と都会因子及び農村因子との関連をみるために 都会地及び農村地帯における累積居住年数を 3 群間で比較したのが表 3 である。なお，調査票 上の質問は，出生から現在までの居住地並びに 転居年月を全部あげて，各居住地毎にそれが， (1)都会地か(2)農村地帯か(3)そのどちらでもない かを患者自身に判断させたものである．更に 3 群間の 現居住 地域による偏りを少なくするた

表 2 地域分布（東京大学附属病院・耳鼻科）

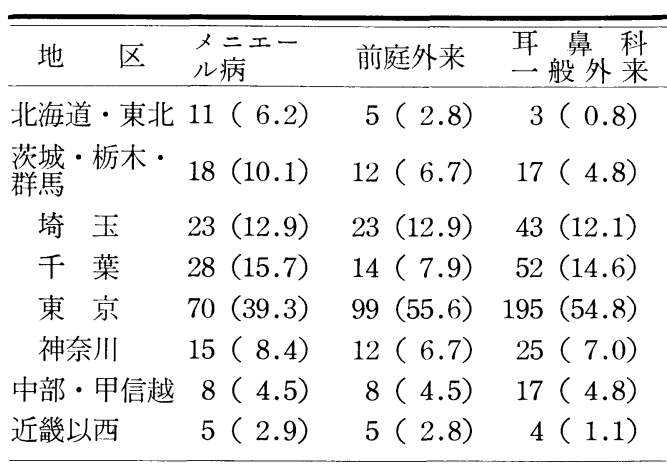

計 $178(100 \%) 178(100 \%) 356(100 \%)$

表 3 都会地及び農村地帯における居住年数

\begin{tabular}{lccc}
\hline \multicolumn{1}{c}{ 居住年数 } & $\begin{array}{c}\text { メ } \text { ル 病 } \\
\text { 前庭外来 }\end{array}$ & 一般外来 \\
\hline 都会地居住累積年数 & & & \\
平均値 & & & \\
標準偏差 & 18.3 年 & 36.2 年 & 38.0 年 \\
$\quad \mathrm{N}$ & 86 人 & 17.9 & 18.3 \\
農村地帯居住累積年数 & & & 217 人 \\
平均值 & 22.7 & 22.4 & 21.1 \\
標準偏差 & 18.1 & 15.8 & 15.9 \\
$\quad \mathrm{~N}$ & 52 & 77 & 142 \\
発病前 & & & \\
都会地居住累積年数 & & & \\
平均值 & 28.6 & 29.3 & - \\
標準偏差 & 16.3 & 17.0 & - \\
$\quad \mathrm{N}$ & 80 & 108 & - \\
農村地帯居住累積年数 & & & \\
平均値 & 19.8 & 22.0 & - \\
標準偏差 & 13.7 & 14.7 & - \\
$\quad \mathrm{N}$ & 45 & 74 & \\
\hline
\end{tabular}

注 1 : 都会地及び農村地帯の判断は患者自身の判 断による。

注 2 : 性・年令をマッチングした各群から埼玉, 東京, 神奈川の居住者のみを抽出した。
め、現住所が東京，埼玉，神奈川のみの患者 について集計した結果が表 3 である。乙の表を みると, 都会地, 農村地带に特に特徵ずけられ るような要因と，本症との関連については否定 的である. 転居の回数についても検討したが 3 群間で全く差がみられない.

メニエール病群と前庭外来群との発病月の比 較を表 4 亿示す。メニエール病群の発病月は 3 〜 5 月及び $8 \sim 10$ 月の季節の変り目と一致して 增加するが，前庭外来群ではこのような一定の 傾向はみられない.メニエール病群にみられる このような発病月の特徵は, 回転性めまい発作 の発現月分布とも一致するが，特に $3 \sim 6$ 月 は，それ以外の月の 1.5〜 3 倍も発作がより多 く頻発する傾向がある.

職業歴について 3 群間を比較すると, 特に人 ニエール病群に有意に多い職業はないが，激し い騒音又は振動の職業歴を有する者がメニエー ル病群で $30.3 \%$ ，一般外来群で $22.2 \%$ とメ二エ 一ル病群に若干多くなっている $\left(\mathrm{X}^{2}=3.13\right.$, 自 由度=1). 表 5 に, 3 群の難聴域を示す. 3 群 とも低音域の難聴者が最も多く，次いで高音域 の難聴者が多い. メニエール病群の聴力障害型 と他の 2 群のそれとを比較すると, メニエール

表 4 発病 月

\begin{tabular}{ccc}
\hline 発病月 & $x=$ エール病 & 前庭外来 \\
\hline 1 月 & $9(6.4)$ & $12(8.9)$ \\
2 & $10(7.1)$ & $12(8.9)$ \\
3 & $15(10.7)$ & $11(8.1)$ \\
4 & $22(15.7)$ & $12(8.9)$ \\
5 & $15(10.7)$ & $13(9.6)$ \\
6 & $11(7.9)$ & $11(8.1)$ \\
7 & $5(3.6)$ & $6(4.4)$ \\
8 & $15(10.7)$ & $11(8.1)$ \\
9 & $14(10.0)$ & $14(10.4)$ \\
10 & $14(10.0)$ & $16(11.9)$ \\
11 & $4(2.9)$ & $4(3.0)$ \\
12 & $6(4.3)$ & $13(9.6)$ \\
不 明 & 38 & 43 \\
\hline 計 & $178 \quad 100 \%$ & $178100 \%$
\end{tabular}


表 8 誘因

\begin{tabular}{|c|c|c|}
\hline $\begin{array}{l}\text { 病気を誘発しや } \\
\text { 寸い発作) }\end{array}$ & $x= \pm ー ル$ 病 & 一般外来 \\
\hline 精神的過労 & $105(59.0)$ & $70(19.7)$ \\
\hline 肉体的過労 & $67(37.6)$ & $51(14.3)$ \\
\hline 感情動 摇 & $44(24.7)$ & $24(6.7)$ \\
\hline 気圧変化 & $34(19.1)$ & $26(7.3)$ \\
\hline 強大音響 & $15(8.4)$ & $21(5.9)$ \\
\hline 乗車 & $11(6.2)$ & $8(2.2)$ \\
\hline 飲 & $8(4.5)$ & $2(0.6)$ \\
\hline 紧 & $7(3.9)$ & $5(1.4)$ \\
\hline 睡眠不足 & $70(39.3)$ & $38(10.6)$ \\
\hline 風 邪 & $25(14.0)$ & $58(16.3)$ \\
\hline 経 & $4(4.8)$ & $2(1.2)$ \\
\hline 妊 & $1(1.2)$ & $1(0.6)$ \\
\hline 出 & $1(1.2)$ & $0(0.0)$ \\
\hline 入 & $1(0.5)$ & $8(2.2)$ \\
\hline な & $4(2.2)$ & 48 (13.5) \\
\hline その 他 & $14(7.9)$ & $23(6.5)$ \\
\hline 患者の総数 & $178(100)$ & $356(100)$ \\
\hline
\end{tabular}

較してみると，味覚ではメニエール病群にやや すっぱいものを好む傾向（メニエール病群 21.1 $\%$ ，前庭外来群 $14.0 \%$ ，一般外来群 $15.9 \%$ ） が みられるが，塩味，甘味，にが味，わさび等の 刺激性味覚, その他清涼飲料水, 果物類などの 嗜好は 3 群間で差異がみられない。

発病時における家畜，家禽類の飼育状況では 牛, 馬, 豚, 犬, 山羊では差がないが, 猫がメ ニエール病群で28名 $(15.7 \%)$ と他の 2 群（前 庭外来群 16 名 $(9.0 \%)$, 一般外来群 27 名 $(6.7 \%))$ に比して有意に（P<0.01）高い值である. 他 にメニエール病群で小鳥が若干高い(20名(11.2 \%)）という印象があるが，有意の差ではない。 鶏については，メニエール病群（13名: 7.3\%） 並びに 前庭外来群 (17名：9.6\%) が，一般外 来群 (17名：4.8\%) と比して 若干高い值であ り, 前庭外来群と一般外来群との間には有意差 $(\mathrm{P}<0.05)$ がみられる.

同一親族における耳疾患患者の有無について みると、メニエール病群では51名 $(28.7 \%)$ の 親族に，前庭外来群では42名 $(23.6 \%)$, 一般
外来群では90名 $(25.3 \%)$ の親族に耳疾患患者 がみられるが，てれら 3 群の間で発現率に有意 差はみられない。また血縁の強さ別にみても， 3 群間で差はみられない。

同一親族における耳嗚りを伴った難聴患者の 有無についてみると，メニエール病群では31名 (17.4\%)の親族に，前庭外来群では28名 (15.7 $\%)$, 一般外来群では 53 名 (14.9\%) の親族に, 耳鳴・難聴者がみられるが 3 群間で有意の差は ない、親族の内訳をみると，メニエール病群の 兄弟姉妹で耳鳴・難聴者は13名 $(7.3 \%)$, 前庭 外来群では 6 名 $(3.4 \%)$, 一般外来群では 16 名 $(4.5 \%)$ と若干メニエール病群の sibship に 耳鳴・難聴者が多いが，3群間で有意の差では ない。

発病年次別にメニエール病患者の発病平均年 令をみたのが表 9 である。乙の表をみると, メ ニエール病群の発病年令は, 年次を追って確実 に上昇している.

メニエール病患者について, 発病年と難聴域 との関係をみると，低音障害型が 34 年以前： $52.9 \%, 35 \sim 39$ 年 : $55.0 \%, 40 \sim 44$ 年 : $65.8 \%$ ， 45～50年： $66.7 \%$ と増加してきている.

調査票には発作の最終発現年月を記載する欄 があり，現在までの発作停止期間が計算でき る.てれによって,メニエール病群の発作停止 期間と, 性, 発病年令との関連をみたのが表 10

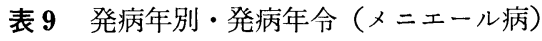

\begin{tabular}{lrrrrl}
\hline \hline 発病年 & $\sim 34$ & $35 \sim 39$ & $40 \sim 44$ & $45 \sim 50$ 年 \\
\hline 平均発病年令 & 30.9 才 & 38.1 才 & 41.3 才 & 43.9 才 \\
標 準 偏 差 & 12.9 & 11.0 & 11.8 & 12.0 \\
人 & 数 & 51 & 40 & 38 & 39
\end{tabular}

表10 発作停止期間と性比及び平均発病年令 (メニエール病)

\begin{tabular}{ccccc}
\hline 発作停止期間 & 男 & 女 & 性比 & $\begin{array}{c}\text { 平均発病年令 } \\
(\mathrm{S} . \mathrm{D} .)\end{array}$ \\
\hline 年 & 人 & 人 & & 才 \\
$0 \sim 2$ & 28 & 30 & 0.93 & $38.6(12.9)$ \\
$3 \sim 9$ & 28 & 21 & 1.33 & $36.5(13.7)$ \\
$10 \sim$ & 15 & 9 & 1.67 & $34.6(11.6)$
\end{tabular}


である。この表をみると，発作停止期間の長い 群ほど男性患者の割合が多く（発作停止期間 0 $\sim 2$ 年の 性比 $0.93,3 \sim 9$ 年 $1.33,10$ 年以上 1.67), 発病年令が低い（発作停止期間 $0 \sim 2$ 年38.6才， $3 \sim 9$ 年36.5才，10年以上 34.6 才). 発作の停止期間が 5 年以上と長い群の発病後に おける都会地居住年数は13.3年であり， 4 年以 下の群のそれ（6.4年）とくらべて 2 倍も長い。 しかし，発病後における農村地带での居住年数 は両群間で差がみられない。

発作停止期間と 既往症との 関係を表 11 亿示 す。発作停止期間 5 年以上の群で，既往症を有 するメニエール病患者は46名 $(85.2 \%)$ あり, 4 年以下群のそれ $(60$ 名 $(77.9 \%))$ と著差はな い. しかし，既往症を個別的にみると，動脈硬 化，高血圧，低血圧，脳血管障害，心・血管疾 患などの循環器系の異常において, 発作停止期 間の短い（4 年以下）群が長い（5 年以上）群 に比してむしろ多くなっている。

発作の停止期間とメニエール病患者の喏好と の関係をみると，停止期間の短い（4 年以下） 群は長い群（5 年以上）に比して, 塩味の濃い もの (24名: $31.2 \% ， 12$ 名: $22.2 \%)$ ，わさび。 こしょうなど刺激の強いもの（32名：41.6\%, 16名：29.6\%）を好む傾向がみられ，果物類に 対する赀好（37名：48.1\%，32名：59.3\%）が 減少する。

表12に，メニエール病群における発作停止期 間と家畜・家禽類の飼育の状況（発作時）との 関連を示す. 何らかの動物を発病時に飼育し ていた者は，発作停止期間 4 年 以下群で 43 名 $(55.8 \%) ， 5$ 年以上群で19名 $(35.2 \%)$ で有意 に（P<0.05）停止期間の短い群に飼育者の割 合が高い。飼育動物別にみると, 小鳥, 猫, 犬，牛，馬において高く，特に小鳥は，限界危 険率 $7 \%$ で両群間に有意差を認めることができ る。
表11 発作停止期間と既往歴

（メニエール病）

\begin{tabular}{|c|c|c|}
\hline \multirow{2}{*}{ 既往歴 } & \multicolumn{2}{|c|}{ 発作停止期間 } \\
\hline & $0 \sim 4$ 年 & 5 年 \\
\hline 中耳炎 & $\begin{array}{r}\% \\
17(22.1)\end{array}$ & $16(29.6)$ \\
\hline 耳管カタル & $3(3.9)$ & $2(3.7)$ \\
\hline 頭頸部外傷 & $2(2.6)$ & $1(1.9)$ \\
\hline 結核 & $8(10.4)$ & $6(11.1)$ \\
\hline 梅 毒 & $1(1.3)$ & $0(0)$. \\
\hline 動脈硬化 & $4(5.2)$ & $0(0)$. \\
\hline 高 血 圧 & $8(10.4)$ & $1(1.9)$ \\
\hline 低 血 圧 & $11(14.3)$ & $2(3.7)$ \\
\hline 脳血管障害 & $3(3.9)$ & $1(1.9)$ \\
\hline 糖 尿 病 & $3(3.9)$ & $0(0)$. \\
\hline 心・血管疾患 & $4(5.2)$ & $1(1.9)$ \\
\hline 頸 椎 症 & $4(5.2)$ & $0(0)$. \\
\hline アレルギー & $10(13.0)$ & $6(11.1)$ \\
\hline な し & $17(22.1)$ & $8(14.8)$ \\
\hline その 他 & $13(16.9)$ & $7(13.0)$ \\
\hline 計 & 108 & 51 \\
\hline 患者の総数 & $77100 \%$ & $54100 \%$ \\
\hline あ & 60 & 46 \\
\hline
\end{tabular}

表12 発作停止期間と家禽類の飼育

(メニエール病 $)$

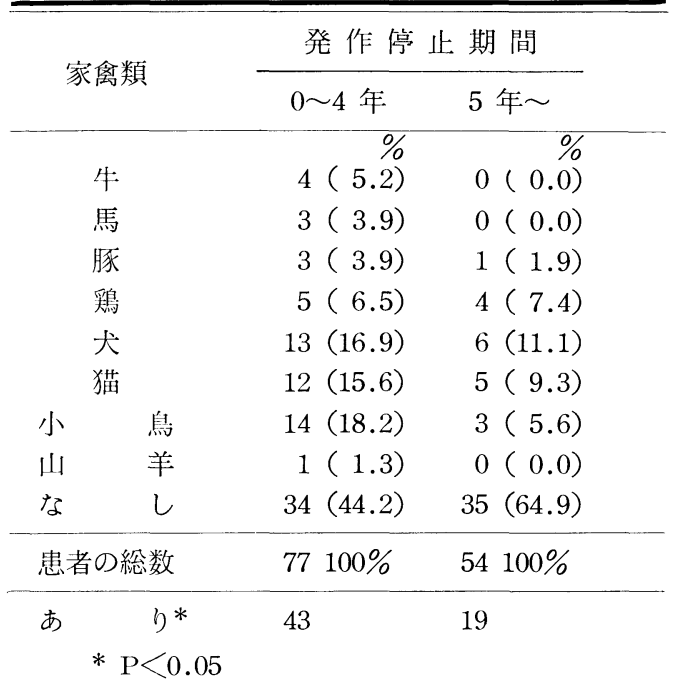


考

ケース・コントロール研究の最大の問題点 は, コントロール群のとり方にあり, ケース群 の諸特性（性, 年令, 居住地, 人種, 社会, 階 層など）に応じて層別された抽出が必要とされ る。しかしながら, 所要の手間と経費の問題, 回収率及び回答の信頼性の問題並びに層別を可 能にする対照群の情報に限度があるため, 通常 は性・年令程度のマッチングを同一施設内で行 うのが一般的なケース・コントロール研究のや り方である.しかしながらケース・コントロー ル研究は, コントロール群が本来とのように母 集団を代表する保証がなく，理論的にケースと コントロール群の comparability が成立して いるという保証もないので, 得られた知見はあ くまで仮説の域にとどまり，今後の詳細な検討 を必要とするものであろう。

本調査は調查票を郵送し, 患者自身に回答を 指示した既往調査であり, 患者の記憶違い, 虚 偽の回答があったとしても，それをチェックす る方法をもたない点に大きな問題点がある。し かしながら,一般的な社会調査とは異り, 調査 者と被調査者の関係が主治医と患者の関係であ る（あった）乙と,方法の項でのべた如く, 調査 票のチェックにおいて，一見してわかる虚偽や あいまいな回答の多い調査票は除いたてと，自 由回答欄に自己の現症, 症状の経過, 医学上の 質問, 調査への励しなど真剣かつ詳細な記述が 数多く記入されているてとなどから判断すれ ば, 回答の信頼性はある程度保証されたと判断 される。

本調査では $2 つ の$ 対照群を用いてメニエール
察

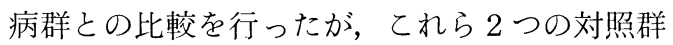
がいずれも耳鼻咽喉科受診患者であったため, 既往歴における中耳炎，親族における耳疾患患 者の有無などは比較に耐えない項目である。耳 鼻疾患以外の項目については, 一応比較に耐え 得ると判断される.

本調査で明らかにされた知見のなかには，誘 因における精神的, 肉体的過労, 不眠, 感情の 動摇, 気圧の変化など, 水越らの全国調查成 績 ${ }^{3)}$ と一致する知見が多い. 合併症の低血圧が メニエール病群に有意に高かったてとについて は, 一つの迷路自律神経反射のあらわれとも解 釈できる、なお, 職業歴, 嗜好, 既往歴, 親族 における難聴・耳鳴者の有無などでは，3群間 に顕著な差がみられなかった，都会的因子，農 村的因子と本症との関連については否定的知見 を得たが，乙れは特に，都会や農村に多い要因 （例えば大気污染など）を否定したもので，本 症を文明病とする考え方 ${ }^{1)}$ と必ずしも矛盾する ものではないと考える.

発病時の家音・家禽類のなかで，猫がメ二エ 一ル病群に有意に多く飼育されていたてと, 及 び発作が 5 年以上も停止しているメニエール病 群では，小鳥，猫，犬，牛，馬などの飼育が， 発作停止期間の短い（4年以下）群に比して少 いことがわかったが興味ある知見である。内藤 は, Levy の犬毛, Strandbygaad の羽毛, 獣 毛による本症のアレルギ一症例報告を紹介して いるが゙1，上記の知見がてのようなアレルギー 説を示唆するものなのか否かは, 今後の検討に まちたい。

\section{ま と め}

東大病院耳鼻咽喉科におけるメニエール病のケース・コントロール研究により次の示唆を得た.

1 都会地, 農村地帯に特徵ずけられる環境要因と本症との関連については否定的である.

2 本症患者の発病月は, $3 \sim 5$ 月及び $8 \sim 10$ 月の季節の変り目と一致して増加し, 特に $3 \sim 6$ 月 は, 1.5〜 3 倍も発作がより多く頻発する.

3 職業歴, 既往歴, 親族中の耳疾患患者については, ケース・コントロール間で差異がない。 
4 発作時における合併症では，低血圧症が本症患者に有意に高い.

5 発病の誘因では, 精神的過労, 肉体的過労, 感情の動摇, 気圧の変化, 乗車, 飲食, 睡眠不足 が本症患者群に有意に高く, 強大音響, 契煙, 月経も有意ではないがやや多い傾向を有する.

6 味覚では, 本症群にややすっぱいもの好む傾向がみられる.

7 発病時における家畜・家禽類の飼育状況では, 猫の飼育が本症群に有意に多い.

8 本症患者の発病年令は, 年次を追って確実に上昇している。また低音障害型の割合が増加して いる.

9 発作停止期間の長い群ほど男性患者の割合が多い.

10 発作停止期間の長い群は短い群に比して, 発病後における都会地居住年数が 2 倍も長い. しか し，発病後における農村地带での居住年数は，両群間で差がない。

11 発作停止期間の短い群は長い群に比して, 動脈硬化, 高血圧, 低血圧, 脳血管障害, 心・血管 疾患などの循環器系の障害をより多く有する. 短い群の現在年令の平均は, 長い群のそれとほぼ

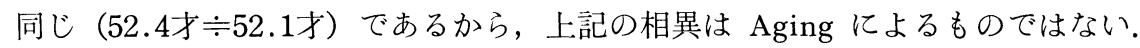

12 発作停止期間の短い群は長い群に比して，塩味の濃いもの，わさび・こしょうなど刺激の強い ものを好む傾向がみられ，果物類に対する嗜好が減少する.

13 発作停止期間の短い群は長い群に比して, 有意に, 家畜・家禽類（特に小鳥）の飼育割合が多 い.

\section{参 考 文 献}

1) 内藤僬, 他 : メニエール病, 林病因, 医学書院. 1964.

2) 渡辺觔：厚生省研究班のメニエール病診断基準に ついて. 耳鼻臨床 $69: 301-303,1976$.
3 ) 水越鉄理, 他 : 厚生省特定疾患 $x= \pm ー ル$ 病調査 研究班によるメニエール病の疫学調査と症状調査. 耳鼻臨床 $70: 1669-1686,1977$. 